\title{
Erratum
}

\section{T cell lymphoproliferative disorder ensuring bone marrow transplantation in a case with severe aplastic anemia}

\author{
L-C Wang, M-Y Lu, J Yu, S-T Jou, I-P Chiang, K-H Lin and D-T Lin
}

Bone Marrow Transplantation 2000; 26: 893-897

Since publication of the above paper, a typesetting error has been identified.

The figure legend for Figure 1 should read 'PCR amplification of the TCR- $\gamma$ chain gene ...' and not 'PCR amplification of the TRC- $\gamma$ gene...'

Please see the corrected version below.

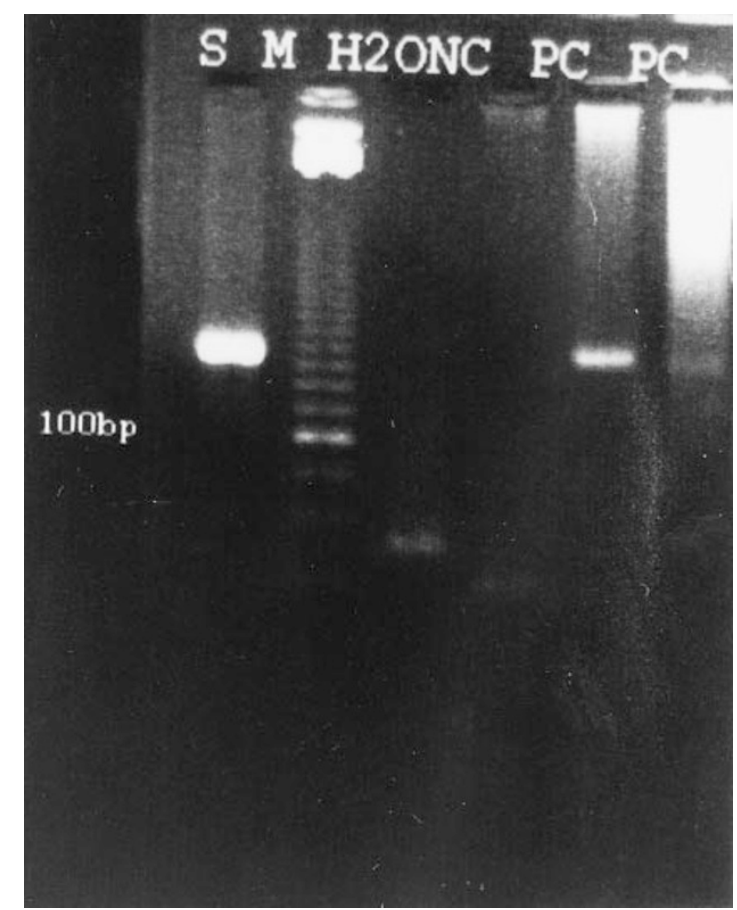

Figure 1 PCR amplification of the TCR- $\gamma$ chain gene. In the $\gamma$ III reaction (VrII $+\mathrm{Jr} 1 / 2$ with product size approximately $150-180 \mathrm{bp}$ ), the patient's specimen revealed a single sharp band about $180 \mathrm{bp}$, indicating the presence of TCR- $\gamma$ chain gene rearrangement. S, patient; $\mathrm{M}$, size marker; $\mathrm{H}_{2} \mathrm{O}$, negative control; $\mathrm{NC}$, follicular lymphoma, negative control; $\mathrm{PC}$, positive control. 